\title{
TINDAK TUTUR PERMINTAAN DALAM BAHASA INDONESIA DI KALANGAN MAHASISWA
}

\author{
Ari Listiyorini \\ Jurusan Pendidikan Bahasa dan Sastra Indonesia \\ Fakultas Bahasa dan Seni, Universitas Negeri Yogyakarta
}

\begin{abstract}
This study aims to describe the speech act of requests in Indonesian, their determinant factors, and their special functions. The data sources were spoken requests by students. The data were collected by taping them and were analyzed by grouping them and interpreting them contextually. The results show that there are direct and indirect requests. Direct requests are made in imperatives, and indirect requests are made in statements or questions. Sometimes a combination of an imperative and a question and that of a question and a question are employed in requests. Politeness in requests is marked by certain expressions, such as tolong, ayolyolyok/yuk, mari, coba, maaf and mohon. The social context influencing the choice of requests includes the intimacy of the speaker and interlocutor, the speech situation, the age difference between the speaker and interlocutor, and the speaker's cultural background. The special functions of requests include that of asking for or borrowing an object, of asking the interlocutor to do something, of welcoming, of inviting, and of prohibiting.
\end{abstract}

Keywords: speech act, form, function, politeness

\section{A. PENDAHULUAN}

Bahasa merupakan sebuah sistem yang digunakan oleh manusia untuk saling berhubungan antara satu dengan yang lain. Pemakaian bahasa pada dasarnya memperlihatkan bahwa seorang penutur menghasilkan tuturan dalam konteks tertentu dan sesaat kemudian ditafsirkan oleh mitra tutur. Penafsiran makna tuturan bahasa tidak hanya ditentukan oleh kaidah-kaidah internal bahasa, tetapi juga ditentukan oleh faktorfaktor yang ada secara keseluruhan yang tidak dapat diperikan sebagai bagian dari sistem bahasa.

Untuk mencapai tujuan tertentu dalam komunikasi seseorang harus menggunakan strategi bertutur yang tepat. Strategi bertutur dapat diimplikasikan melalui pemilihan bentuk-bentuk tuturan tertentu dengan melihat konteks sosiokultural yang melatarinya. Penggunaan bahasa (strategi bertutur) dalam komunikasi ini, terutama hubungan di antara bentuk tuturan dan konteks serta penggunaan bentuk tuturan itu dipelajari dalam pragmatik.

Salah satu penelitian yang sering dilakukan dalam kajian pragmatik adalah tindak tutur (speech act). Tindak tutur artinya dalam melakukan komunikasi linguistis seseorang bukan hanya menyampaikan proposisi atau informasi, tetapi juga melakukan tindakan (action). Tindak tutur dalam ujaran suatu kalimat mengandung prinsip adanya kemungkinan menyatakan secara tidak tepat apa yang dimaksud oleh penutur (Verhaar, 2001: 16). Hal ini berkaitan dengan strategi atau siasat untuk membuat mitra tutur melakukan atau tidak melakukan sesuatu sesuai dengan isi ujaran yang disampaikan penutur.

Dalam percakapan sehari-hari yang dimaksudkan penutur sering berbeda dengan makna literal yang dituturkan.

(1) "Rin, kecilkan volume radionya! Bising sekali nih." 
(2) "Bisa tidak, kecilkan volume radionya?”

(3) "Wah saya kok tidak nyaman dengan suara radiomu itu."

Dalam tuturan-tuturan di atas terdapat contoh tuturan yang bermaksud meminta pada mitra tuturnya. Penutur menginginkan mitra tuturnya melakukan sesuatu tindakan seperti yang dikehendakinya. Akan tetapi, maksud tersebut dapat dinyatakan dengan bentuk yang berbeda. Pemilihan tuturan tersebut tergantung siapa mitra tuturnya, untuk tujuan apa, dalam situasi apa, dan sebagainya.

Bentuk-bentuk permintaan dalam tuturan (1)-(3) di atas direalisasikan secara langsung dan secara tidak langsung. Permintaan dalam tuturan (1) diungkapkan secara langsung dengan kalimat perintah, permintaan dalam tuturan (2) diungkapkan secara tidak langsung dengan kalimat tanya, dan permintaan dalam tuturan (3) diungkapkan secara tidak langsung dengan kalimat berita.

Dalam penelitian ini akan dianalisis tindak tutur permintaan di kalangan mahasiswa. Yang menjadi pertanyaan kemudian adalah bagaimana seorang mahasiswa melakukan tindak tutur untuk meminta pada mahasiswa lain? Bentuk-bentuk tuturan apakah yang digunakan untuk meminta pada orang lain? Apakah mereka memperhatikan kesantunan dalam tindak tuturnya? Faktor-faktor apakah yang mempengaruhi pemilihan tindak tutur permintaan di kalangan mahasiswa? Fungsifungsi khusus apakah yang terkandung dalam tindak tutur permintaan tersebut? Pertanyaanpertanyaan tersebut akan dijawab melalui penelitian ini. Dengan demikian, tujuan penelitian ini adalah (a) mendeskripsikan bentuk-bentuk tindak tutur permintaan dalam bahasa Indonesia di kalangan mahasiswa, (b) mendeskripsikan faktor-faktor yang mempengaruhi pemilihan tindak tutur permintaan dalam bahasa Indonesia di kalangan mahasiswa, dan (c) mendeskripsikan fungsi-fungsi khusus tidak tutur permintaan dalam bahasa Indonesia di kalangan mahasiswa.
Pragmatik sebagai salah satu cabang linguistik mulai berkumandang dalam percaturan linguistik Amerika sejak tahun 1970-an. Sebelumnya ilmu ini hanya dianggap sebagai keranjang tempat penyimpanan data yang bandel, yang tidak terjelaskan, dan yang boleh dilupakan dengan mudah (Leech, 1993: 1). Kemunculan ilmu ini timbul dengan adanya kesadaran bahwa linguistik tidak dapat dipisahkan dari masyarakat dengan segala latar belakang sosiokultural yang melatarbelakanginya.

Levinson (via Rahardi, 2005: 48) mendefinisikan pragmatik sebagai studi bahasa yang mempelajari relasi bahasa dengan konteksnya. Konteks yang dimaksud tergramatisasi dan terkodifikasi sehingga tidak dapat dilepaskan dari struktur bahasanya.

Definisi pragmatik juga dikemukakan oleh Mey (1993). Mey mendefinisikan pragmatik sebagai the studi of the conditition of human language uses as the are determined by the context of society (1993:42). Pragmatik didefinisikan sebagai ilmu bahasa yang mempelajari kondisi penggunaan bahasa manusia yang pada dasarnya sangat ditentukan oleh konteks yang mewadahi dan melatarbelakangi bahasa itu. Konteks yang dimaksud adalah segala latar belakang pengetahuan yang dimiliki bersama oleh penutur dan mitra tutur serta yang menyertai dan mewadahi sebuah pertuturan. Konteks demikian disebut oleh Wijana sebagai konteks situasi tutur(1996: 10-11).

Pragmatik mempelajari apa saja yang termasuk struktur bahasa sebagai alat komunikasi antara penutur dan mitra tutur serta pengacuan tanda-tanda bahasa yang sifatnya ekstralinguistik. Leech (1993) menyatakan bahwa fonologi, sintaksis, dan semantik merupakan bagian dari tata bahasa atau gramatika sedangkan pragmatik merupakan bagian dari penggunaan tata bahasa.

Tindak tutur artinya dalam melakukan komunikasi linguistik seseorang tidak hanya menyampaikan proposisi atau informasi, tetapi juga melakukan tindakan. Tindak tutur itu sendiri pada dasarnya merupakan pernyataan 
konkret dari fungsi-fungsi bahasa. Terdapat tiga jenis tindak tutur, yaitu (1) tindak lokusioner, (2) tindak ilokusioner, dan (3) tindak perlokusioner (Searle, dalam Rahardi, 2005: 35). Tindak tutur lokusioner adalah tindak bertutur dengan kata, frase, dan kalimat sesuai dengan kata yang dikandung oleh kata, frase, dan kalimat itu. Dalam tindak ini tidak dipermasalahkan maksud dan fungsi tuturan yang disampaikan oleh penutur. Selanjutnya tindak ilokusioner adalah tindak melakukan sesuatu dengan maksud dan fungsi tertentu pula. Yang terakhir tindak perlokusioner adalah tindak menumbuhkan pengaruh kepada mitra tutur.

Sebuah maksud tuturan dapat diungkapkan dengan berbagai macam bentuk tindak tutur. Oleh karena itu, tidak semua tuturan memiliki modus dan makna yang sama dengan maksud penuturnya. Maksud tuturan tersebut dapat diketahui dari konteks yang melatarinya Sebagai contoh, kalimat berita tidak selalu berfungsi untuk menyatakan sesuatu, tetapi juga dapat untuk maksud memerintah.

Berdasarkan modus dan maknanya tindak tutur dapat dibedakan menjadi tindak tutur langsung dan tindak tutur tidak langsung serta tindak tutur literal dan tindak tutur tidak literal (Wijana, 1996: 30). Tindak tutur langsung ialah tindak tutur yang diutarakan dengan modus kalimat yang sama dengan maksud pengutaraannya. Maksud memberitahu dengan kalimat berita, maksud menanyakan sesuatu dengan kalimat tanya, dan maksud memerintah diutarakan dengan kalimat perintah. Tindak tutur tidak langsung ialah tindak tutur yang diutarakan dengan modus kalimat yang tidak sesuai dengan maksud penutur. Maksud memerintah dapat diutarakan dengan kalimat tanya atau kalimat berita. Tindak tutur literal ialah tindak tutur yang maksudnya sama dengan makna kata-kata yang menyusunnya sedangkan tindak tutur tidak literal ialah tindak tutur yang maksud pengutaraannya tidak sama atau berlawanan dengan kata-kata yang menyusunnya (Wijana, 1996:32)
Agar pesan yang disampaikan dalam tindak tutur dapat sampai dengan baik pada peserta tutur ada beberapa prinsip-prinsip yang perlu diperhatikan dalam komunikasi. Prinsipprinsip tersebut oleh Grice disebut sebagai Prinsip Kerja Sama. Prinsip kerja sama Grice ialah sebagai berikut.

1) Maksim Kuantitas (The Maxim of Quantity)

Di dalam maksim kuantitas, seorang penutur diharapkan dapat memberikan informasi yang cukup, relatif memadai, dan seinformatif mungkin. Informasi demikian itu tidak boleh melebihi informasi yang sebenarnya dibutuhkan si mitra tutur.

2) Maksim Kualitas (The Maxim of Quality)

Dengan maksim kualitas, seorang peserta tutur diharapkan dapat menyampaikan sesuatu yang nyata dan sesuai fakta sebenarnya di dalam bertutur. Fakta itu harus didukung dan didasarkan pada buktibukti yang jelas.

3) Maksim Relevansi (The Maxim of Relevance)

Di dalam maksim relevansi, dinyatakan bahwa agar terjalin kerja sama yang baik antara penutur dan mitra tutur, masingmasing hendaknya dapat memberikan kontribusi yang relevan tentang sesuatu yang sedang dipertuturkan itu.

4) Maksim pelaksanaan (The Maxim of Manner)

Maksim pelaksanaan ini mengharuskan peserta petuturan bertutur secara langsung, jelas, dan tidak kabur. Dalam praktik penggunaan bahasa yang sebenarnya Prinsip Kerja Sama Grice lebih sering tidak dipatuhi. Misalnya saja pada masyarakat tutur yang berbudaya Jawa, ketidakjelasan, kekaburan, dan ketidaklangsungan dalam berkomunikasi merupakan hal yang wajar dan sangat lazim terjadi. Pada masyarakat tutur ini, justru ketidaklangsungan merupakan salah satu kriteria kesantunan seseorang dalam bertutur. Selain itu juga semakin panjang tuturan akan semakin sopanlah tuturan itu. Sebaliknya, semakin 
pendek sebuah tuturan, akan semakin tidak sopanlah tuturan itu.

Oleh karena itu, dalam komunikasi lebih banyak digunakan Prinsip Kesantunan daripada Prinsip Kerja Sama. Prinsip Kesantunan ini dirumuskan oleh Leech (1983). Rumusan itu selengkapnya tertuang dalam enam maksim interpersonal sebagai berikut.

1) Maksim kebijaksanaan

a) Minimalkan kerugian orang lain.

b) Maksimalkan keuntungan orang lain.

2) Maksim kedermawanan

a) Minimalkan keuntungan diri sendiri.

b) Maksimalkan pengorbanan diri sendiri.

3) Maksim penghargaan

a) Minimalkan penjelekan/cacian pada orang lain.

b) Maksimalkan pujian pada orang lain.

4) Maksim kesederhanaan

a) Minimalkan pujian pada diri sendiri.

b) Maksimalkan penjelekan/cacian pada diri sendiri.

5) Maksim permufakatan

a) Minimalkan ketidaksesuaian antara diri sendiri dengan orang lain.

b) Maksimalkan kesesuaian antara diri sendiri dengan orang lain.

6) Maksim simpati

a) Minimalkan antipati antara diri sendiri dengan orang lain.

b) Maksimalkan simpati antara diri sendiri dengan orang lain.

7) Maksim pertimbangan

a) Minimalkan rasa tidak senang orang lain

b) Maksimalkan rasa senang orang lain

(Gunarwan, 2003:10-12 dan Tarigan, 1990:8283).

\section{B. METODE PENELITIAN}

Data penelitian ini ialah tuturan permintaan di kalangan mahsiswa dalam lingkungan kampus yang bentuknya lisan. Pengumpulan data dilakukan dengan teknik simak. Teknik simak yang dilakukan ialah teknik simak bebas libat cakap (SLBC). Dalam teknik simak bebas libat cakap peneliti hanya menyimak pertuturan orang lain tanpa berpartisipasi di dalamnya (Sudaryanto, 1993, 133-136).

Analisis data dilakukan dengan mengelompokkan data terlebih dahulu. Klasifikasi data dilakukan untuk mendapatkan tipe-tipe data yang cermat. Selanjutnya data penelitian dianalisis secara kontekstual, yaitu cara-cara analisis yang diterapkan pada data dengan mendasarkan, memperhitungkan, dan mengautkan identitas konteks-konteks yang ada. Konteks merupakan lingkungan di mana bahasa itu digunakan, mencakup lingkungan fisik maupun lingkungan nonfisik.

\section{HA S I L P ENELITIAN DAN PEMBAHASAN}

1. Bentuk-Bentuk Tindak Tutur Permintaan dalam Bahasa Indonesia di Kalangan Mahasiswa

Tindak tutur permintaan dalam bahasa Indonesia di kalangan mahasiswa dapat diungkapkan secara langsung maupun secara tidak langsung. Pemilihan bentuk tuturan ini sangat dipengaruhi konteks tuturan. Berikut ini penjelasan bentuk-bentuk permintaan dalam bahasa Indonesia di kalangan mahasiswa.

\section{a. Tindak Tutur Permintaan secara Langsung}

Tindak tutur permintaan secara langsung ini diungkapkan dengan modus kalimat perintah. Kalimat perintah digunakan sama seperti fungsinya, yaitu untuk memerintah atau meminta. Tindak tutur permintaan secara langsung ini digunakan oleh mahasiswa ketika meminta kepada mahasiswa lain yang hubungannya dekat atau yang usianya sebaya.

(4) "Wan pinjam pulpennya!"

(5) "Yen, sehabis pulang kuliah anterin aku pulang ke kost ya!"

Tuturan (4) dituturkan oleh seorang mahasiswa kepada mahasiswa lain ketika kuliah sedang berlangsung. Penutur tidak 
membawa pulpen untuk mencatat materi kuliah sehingga mahasiswa tersebut meminjam pulpen pada temannya. Tuturan permintaan diungkapkan secara langsung tanpa bertanya terlebih dahulu apakah temannya tersebut membawa pulpen lebih dari satu. Begitu pula dengan tuturan (5) penutur meminta secara langsung pada mitra tuturnya untuk mengantarkan penutur pulang ke kost. Pemilihan bentuk tuturan secara langsung ini disebabkan hubungan antara penutur dan mitra tutur yang dekat dan usia yang sebaya.

\section{b. Tindak Tutur Permintaan secara Tidak Langsung}

Tindak tutur permintaan secara tidak langsung dapat diungkapkan dengan modus kalimat berita, kalimat tanya, maupun kombinasi antara keduanya.

(6) Mhs A: "Besok paling lambat lho ngumpul tugas makalah Sintaksis."

Mhs B: "Ya tadi malam udah tak ketik kok."

(7) "Bih, uang bulanan kamu masih sisa nggak?"

(8) "Disketku mana non?"

Secara literal tuturan (6) berisi informasi yang dituturkan oleh mahasiswa pada mahasiswa lainnya bahwa makalah Sintaksis dikumpulkan paling lambat besok. Akan tetapi, dilihat dari konteksnya tuturan tersebut tidak hanya bertujuan memberi informasi saja, tetapi juga berisi permintaan dari penutur (Mhs A) pada mitra tutur (Mhs B) untuk segera mengetik tugas makalah sintaksisnya. Tuturan (6) konteksnya ialah penutur dan mitra tutur satu kelompok dalam mengerjakan tugas kuliah Sintaksis. Tuturan permintaan dengan modus kalimat berita dituturkan oleh mitra tutur pada mitra tutur baik hubungannya dekat atau kurang dekat, usia sebaya, lebih muda atau bahkan lebih tua.

Begitu pula dengan tuturan (7) dan (8). Secara literal kedua tuturan tersebut berisi pertanyaan. Dalam tuturan (7) penutur menanyakan pada mitra tuturnya apakah uang bulanan mitra tutur masih tersisa dan dalam tuturan (8) penutur menanyakan pada mitra tutur tentang keberadaan disket si penutur.
Dilihat dari konteksnya, sebenarnya kalimat tanya dalam tuturan (7) dan (8) tersebut tidak hanya bertujuan untuk menanyakan sesautu, tetapi juga berfungsi untuk meminta orang lain melakukan suatu tindakan. Tuturan (8) juga tidak hanya membutuhkan jawaban tentang keberadaan disket penuitur, tetapi sebenarnya bermaksud meminta mitra tutur mengembalikan disket penutur.

Dalam tindak tutur permintaan ini, seringkali mahasiswa menggunakan berbagai modus kalimat untuk melakukan tindak tutur permintaan. Dalam tuturan pertama biasanya penutur meminta dengan menggunakan kalimat tanya, tetapi selanjutnya permintaan ditegaskan secara langsung dengan kalimat perintah.

(9) Mhs A: "Fit, besok kamu berangkatnya sama siapa?"

Mhs B: "Sendiri, emang ada apa?"

Mhs A: "Besok aku dijemput di kos ya!"

Dalam tuturan (9) pertama kali penutur bertanya pada mitra tutur tentang dengan siapa mitra tutur berangkat. Setelah mitra tutur tersebut menjawab bahwa dia berangkat sendiri, kemudian penutur meminta mitra tutur menjemputnya di kos.

Selain kombinasi modus kalimat tanya dan kalimat perintah ada pula kombinasi tindak tutur permintaan dengan kombinasi modus kalimat tanya dengan kalimat tanya. Kombinasi tuturan ini dalam tindak tutur permintaan biasanya dilakukan ketika penutur merasa tidak enak meminta (menyuruh) secara langsung kepada mitra tuturnya. Kombinasi tuturan ini terjadi pada penutur yang usianya lebih muda daripada mitra tutur atau usianya sebaya.

(10) Mhs A: "Mbak duitnya masih nggak?"

Mhs B: "Emangnya kenapa?"

Mhs A:"Boleh pinjam 20 ribu nggak mbak?"

(11) Bagaimana tugas kita? Sudah diketik belum?

Tuturan (10) dituturkan oleh mahasiswa yang bermaksud meminjam uang pada mahasiswa yang lebih tua. Tuturan (11) dituturkan oleh mahasiswa yang meminta pada mahasiswa lain dalam satu kelompok untuk 
segera mengerjakan dan mengetik tugas kelompok.

\section{Bentuk-Bentuk Lingual Penanda Kesantunan dalam Tindak Tutur Permintaan di Kalangan Mahasiswa}

Kesantunan dalam tindak tutur permintaan di kalangan mahasiswa salah satunya ditandai dengan penggunaan bentuk-bentuk lingual tertentu. Bentuk-bentuk lingual penanda kesantunan tersebut ialah sebagai berikut.

\section{a. Tolong}

Bentuk penanda kesantunan tolong paling banyak digunakan ketika melakukan tindak tutur permintaan. Penanda kesantunan ini tidak hanya ditujukan pada mitra tutur yang hubungannya kurang dekat atau usianya lebih tua. Akan tetapi, juga kepada mitra tutur yang hubungannya dekat/ sangat dekat bahkan pada mitra tutur yang usianya lebih muda. Dengan menggunakan penanda kesantunan tolong penutur (mahasiswa) dapat memperhalus permintaannya/tindak tutur permintaannya.

(12) "Pis tolong buatin cover buat tugas Linguistik!"

Dalam tuturan (12) digunakan penanda kesantunan tolong walaupun usia mitra tutur sebaya dan hubungan antara penutur dan mitra tutur dekat.

b. Ayo/Yo/Yok/Yuk

Penanda kesantunan Ayo/Yo/Yok/Yuk biasanya ditujukan pada mitra tutur yang usianya sama atau sejajar dan dalam situasi yang informal. Penanda kesantunan ini dapat diletakkan di awal kalimat maupun di akhir kalimat.

(13) "Makan, yok!"

(14) "Ayo, bu Ari sudah masuk tuh!"

Dalam tuturan (13) penanda kesantunan yok diletakkan di akhir tuturan dan penanda kesantunan ayo dalam tuturan (14) diletakkan di awal tuturan.

\section{c. Coba}

Penanda kesantuanan coba digunakan pada mitra tutur yang usianya lebih muda. Dengan penggunaan bentuk coba, seolah-olah mitra tutur diperlakukan sebagai orang yang sejajar dengan penutur.

(15) "Coba dikerjakan sendiri dulu! Kalau tidak bisa nanti mbak bantu."

Konteks tuturan (15) ialah seorang mahasiswa meminta tolong pada mahasiswa kakak angkatan untuk membantu mengerjakan tugas kuliahnya. Kemudian kakak angkatan tersebut (penutur) meminta adik kelasnya untuk mencoba mengerjakan sendiri tugas kuliah itu. Seandainya tidak bisa penutur bersedia membantu.

d. Maaf

Penanda kesantunan maaf digunakan pada mitra tutur yang usianya lebih tua.

(16) "Maaf Mba Ve, bisa minta tolong sms-kan Yudi, bagaimana pamfletnya gitu.

Dalam tuturan (16) penanda kesantunan yang digunakan ialah maaf. Penutur yang usianya lebih muda meminta pada kakak angkatan yang usianya lebih tua untuk mengsms Yudi.

e. Mohon

Penanda kesantunan mohon ternyata juga digunakan mahasiswa untuk meminta pada mahasiswa lain yang usianya sebaya dan hubungannya dekat.

(17) "Temen-temen mohon perhatian sebentar!" Nanti setelah kuliah terakhir kumpul dulu untuk membicarakan tentang rencana kita ke Bali.

Konteks dalam tuturan (17) ialah seorang ketua kelas yang meminta pada temantemannya satu kelas sebelum satu mata kuliah berlangsung untuk berkumpul dahulu setelah kuliah tersebut selesai.

\section{Faktor-Faktor yang Mempengaruhi Pemilihan Tindak Tutur Permintaan di Kalangan Mahasiswa}

Ada beberapa faktor yang mempengaruhi pemilihan tindak tutur permintaan di kalangan mahasiswa. Mahasiswa sebagai penutur dalam kenyataannya tidak akan sama ketika melakukan tindak tutur permintaan. Dalam satu waktu mungkin 
penutur (mahasiswa) tersebut akan meminta secara langsung dengan menggunakan kalimat perintah, tetapi pada lain waktu akan meminta secara tidak langsung dengan menggunakan kalimat tanya atau berita. Perbedaan tindak tutur permintaan di kalangan mahasiswa ini disebabkan oleh faktor-faktor tertentu.

Faktor-faktor yang mempengaruhi pemilihan tindak tutur permintaan di kalangan mahasiswa tersebut ialah sebagai berikut.

\section{a. Kedekatan hubungan antara penutur dan mitra tutur}

Jika hubungan antara penutur dan mitra tutur tersebut dekat atau sangat dekat, maka dipilihlah tindak tutur secara langsung. Modus kalimat yang dipilih ialah kalimat perintah. Akan tetapi, jika hubungan antara penutur dan mitra tutur tidak/kurang dekat maka dipilihlah tuturan permintaan yang tidak langsung, yaitu dengan menggunakan kalimat berita atau kalimat tanya.

(18) "Yen, hari Senin jemput aku ya!"

Tindak tutur permintaan dalam tuturan (18) diungkapkan secara langsung karena hubungan antara penutur dan mitra tutur sangat dekat. Penutur dalam tuturan (18) menyuruh mitra tutur untuk menjemput penutur.

\section{b. Situasi tutur}

Situasi tutur juga berpengaruh dalam pemilihan tindak tutur permintaan ini. Bila situasinya informal maka digunakan tindak tutur permintaan secara langsung. Akan tetapi, bila situasinyaformal, maka digunakan tuturan permintaan secara tidak langsung. Misalnya dalam diskusi di kelas, seorang mahasiswa meminta mahasiswa lain untuk menjelaskan hal-hal yang dianggap belum jelas. Walapun hubungan antara penutur dan mitra tutur tersebut dekat, permintaan diungkapkan secara tidak langsung.

(19) "Apakah perbedaan konkrit antara verba dan adjektiva?"

Penutur dalam tuturan (19) meminta pada mitra tuturnya yang sedang presentasi makalah untuk menjelaskan lagi perbedaan konkrit antara verba dan adjektiva.

\section{c. Usia}

Perbedaan usia antara penutur dan mitra tutur juga berpengaruh terhadap pemilihan tindak tutur permintaan ini. Penutur akan menggunakan permintaan secara langsung dengan kalimat perintah pada mitra tutur yang usianya lebih muda. Tindak tutur ini dengan menggunakan penanda kesantunan atau tidak.

(20) "Mas punya Novel Supernova?"

(21) Yud' kamu ambil backdropnya di Stage belum diambil, nanti sore ya!"

Tuturan (20) dituturkan oleh penutur yang usianya lebih muda daripada usia mitra tutur. Tindak tutur permintaan diungkapkan secara tidak langsung dengan modus kalimat tanya. Sebaliknya, tuturan (21) dituturkan oleh penutur yang usianya lebih tua daripada usia mitra tutur. Tindak tutur permintaan diungkapkan secara langsung dengan modus kalimat perintah.

\section{d. Latar Belakang Budaya Penutur}

Pemilihan tindak tutur permintaan tidak jarang berbeda antara penutur yang berlatar belakang budaya Jawa dengan penutur yang berlatar belakang budaya bukan Jawa. Kalau penutur berlatar belakang budaya Jawa, biasanya dipilihlah tindak tutur secara tidak langsung. Modus kalimat yang digunakan ialah kalimat tanya atau kalimat berita. Biasanya juga digunakan kalimat yang panjang dan dengan basa-basi terlebih dahulu. Penanda kesantunan juga digunakan dalam tindak tutur permintaan ini. Ada budaya ewuh pekewuh bila meminta secara langsung. Hal ini berbeda jika penutur berlatar belakang budaya bukan Jawa. Penutur dengan latar belakang ini biasanya akan meminta secara langsung tanpa tedeng alingaling dengan menggunakan kalimat imperatif. Bukan maksud penutur untuk tidak santun, tetapi budayanya memang seperti itu, berbeda dengan budaya Jawa.

(22) "Mbak besok bukunya dibawa ya! Aku mau ngerjain tugas."

Tuturan (22) dituturkan seorang mahasiswa pada kakak angkatan yang meminjam bukunya. Penutur berasal dari 
budaya nonJawa yang meminta pada orang yang lebih tua secara langsung. Hal ini berbeda dengan budaya Jawa yang ada rasa tidak kepenak untuk meminta buku secara langsung walaupun yang diminta buku milik penutur tersebut. Penutur dengan budaya Jawa kemungkinan akan meminta secara tidak langsung karena takut mitra tutur tersinggung atau malu.

\section{Fungsi-fungsi Khusus Tindak Tutur Permintaan dalam Bahasa Indonesia di Kalangan Mahasiswa}

Penelitian ini menganalisis tindak tutur permintaan dalam bahasa Indonesia di kalangan mahasiswa. Dalam hal ini, tindak tutur berfungsi untuk menyampaikan maksud bahwa penutur menginginkan mitra tuturnya melakukan sesuatu tindakan seperti yang diinginkan oleh penutur. Fungsi umum tersebut dapat diuraikan lagi menjadi fungsi-fungsi yang lebih khusus. Fungsi-fungsi tersebut ialah sebagai berikut.

\section{a. Meminta/meminjam sesuatu benda}

Tindak tutur permintaan dapat dilakukan ketika mahasiswa sebagai penutur hendak meminta atau meminjam sesuatu benda kepada mahasiswa lain sebagai mitra tuturnya.

(23) "Minta dikit ya minumnya!"

Tuturan (23) dituturkan oleh seorang mahasiswa kepada mahasiswa lain ketika sedang berada di kantin. Konteks tuturan tersebut ialah penutur hanya duduk-duduk bersama mahasiswa lain tidak pesan makan. Selanjutnya penutur minta minum pada mahasiswa lain yang sedang makan di kantin tersebut.

\section{b. Menyuruh mitra tutur melakukan tindakan tertentu}

Selain fungsi meminta atau meminjam, tindak tutur permintaan juga berfungsi untuk menyuruh mitra tutur melakukan sesuatu. Penanda lingual yang digunakan ialah tolong danjangan.

(24) Die, jawaban nomor dua apaan?

Tuturan (24) dituturkan seorang mahasiswa pada saat ujian pengambilan nilai berlangsung. Mahasiswa tersebut meminta mahasiswa lain untuk melakukan tindakan tertentu, yaitu memberi jawaban atas soal nomor dua.

\section{c. Mempersilakan}

Fungsi khusus selanjutnya ialah mempersilakan. Tuturan yang berfungsi untuk mempersilakan ini tidak ditandai dengan bentuk lingual tertentu, misalnya silakan.

(25) "Mbak duluan aja!"

Tuturan (25) dituturkan oleh mahasiswa yang antri di kamar kecil. Penutur mempersilakan mahasiswa lain yang usianya lebih tua untuk masuk terlebih dahulu.

\section{d. Mengajak}

Fungsi mengajak ini biasanya ditandai dengan bentuk lingual Ayolyo/yok/yuk atau mari. Tuturan ajakan dengan penanda Ayolyo/yok/yuk dituturkan oleh penutur pada mitra tutur yang usianya sebaya atau lebih muda dan hubungannya dekat. Bila hubungannya kurang dekat dan usianya lebih tua penanda lingual yang digunakan ialah mari.

(26) "Ke kantin, yuk!"

Tuturan (26) berisi ajakan ke kantin yang dituturkan penutur pada mahasiswa yang usianya sebaya.

\section{e. Melarang}

Tindak tutur permintaan ini juga dapat berfungsi untuk melarang mitra tutur melakukan suatu tindakan. Bentuk lingual yang digunakan untuk menandai fungsi ini ialah jangan.

(27) Mhs A: "Yul aku pinjam jadwal ujian semester!"

Mhs B: "Iya boleh, tapi jangan dibawa pulang ya!"

Dalam tuturan (27) penutur melarang mitra tutur membawa pulang jadwal ujian semester milik penutur.

\section{PENUTUP}

Tindak tutur permintaan di kalangan mahasiswa dapat diungkapkan dengan dua bentuk, yaitu secara langsung maupun tidak langsung. Kedua bentuk tindak tutur 
permintaan tersebut dapat diungkapkan dengan modus kalimat perintah, kalimat, tanya, atau kalimat berita. Dalam pengungkapan tindak tutur permintaan yang dilakukan oleh mahasiswa ternyata juga digunakan penanda kesantunan yang diungkapkan dengan bentuk lingual tolong, ayolyolyok/yuk, mari, coba, maaf dan mohon.

Pemilihan tindak tutur permintaan di kalangan mahasiswa tidak terlepas dari konteks sosial budaya yang melatarbelakangi tuturan tersebut. Faktor-faktor yang mempengaruhi pemilihan tindak tutur permintaan di kalangan mahasiswa tersebut ialah: kedekatan hubungan antara penutur dan mitra tutur, situasi tutur, perbedaan usia antara penutur dan mitra tutur, dan latar belakang budaya penutur.

Tindak tutur permintaan di kalangan mahasiswa mempunyai fungsi-fungsi khusus, yaitu: fungsi meminta/meminjam sesuatu benda, menyuruh mitra tutur melakukan tindakan tertentu, mempersilakan, mengajak, dan melarang.

\section{DAFTAR PUSTAKA}

Alwi, Hasan, dkk. 2003. Tata Bahasa Baku Bahasa Indonesia. Jakarta: Balai Pustaka.

Chaer, Abdul. 1994. Linguistik Umum. Jakarta: Rineka Cipta.
Gunarwan, Asim. 2003. "Beberapa Prinsip dalam Komunikasi Verbal: Tinjauan Sosiolinguistik dan Pragmatik". Makalah disampaikan dalam PIBSI XXV di Yogyakarta, 6-7 Oktober 2003.

Leech, Geoffrey. 1993. Prinsip-Prinsip Pragmatik. Diterjemahkan oleh M.D.D. Oka; pendamping Setyadi Setyapranata. Jakarta: Penerbit Universitas Indonesia.

Mey, Jakob L. 1993. Pragmatics: An Introduction. Oxford: Blackwell Publishers.

Rahardi, Kunjana. 2005. Pragmatik: Kesantunan Imperatif Bahasa Indonesia. Bandung: Erlangga.

Ramlan, M. 1987. Sintaksis. Yogyakarta: CV Karyono.

Soeparno. 2002. Dasar-Dasar Linguistik Umum. Yogyakarta: Tiara Wacana.

Sudaryanto. 1993. Metode dan Teknik Analisis Bahasa. Yogyakarta: Duta Wacana University Press.

Verhaar, J.W.M. 2001. Asas-Asas Linguistik Umum. Yogyakarta: Gadjah Mada University Press.

Wijana, I Dewa Putu. 1996. Dasar-Dasar Pragmatik. Yogyakarta: Penerbit Andi. 